\title{
National University as a Developer of Social Capital for the Nation
}

\author{
G N Madhuranatha Dixit *
}

\begin{abstract}
Conceiving a national university as a holistic educational organisation that 'looks within' and conducts research endeavours by networking with various institutions/ universities within the country and overseas for the development of the nation is of utmost importance. Education is a social endeavour and it helps in instilling a sense of value and enables people to lead a meaningful life. To achieve the same, the government should implement the reforms and policies with the articipation of the formal, non-formal, and informal institutions to develop a strong social cohesive bond between the various stakeholders. This social strength could be conceived as a social capital that acts as the social cohesive bond and influences both development opportunities and outcomes. In this paper, we attempt to explore the possibility of envisioning a system called a national university to develop social capital for the nation.
\end{abstract}

Keywords: National University, Nation, Comprehensive Outcome, Introspection

\section{Introduction}

The volume "Reimagining India Unlocking the Potential of Asia" (Chandler \& Zainulbhai, 2013) is an important anthology where we initiate our journey to examine the potentials of India as a state and

* Professor of Mathematics (Retired), and former Regional Centre Manager (in-charge of South Asia), Edexcel International, London. Educational Facilitator, gnmdixit@gmail.com 
a social capital. Gurucharan Das (2013, p. 22), an author and a commentator, in this anthology, opines that "India historically is a weak state though balanced by a strong society." Other authors in the same volume including Bill Gates (2013, p. 38) resonate a similar observation. If one examines the approach adopted by Mahatma Gandhi, it becomes quite evident that his studies and observations of the country helped him realize the fabric of the nation, which indubitably was strewn with multiple weaves, but retained its strength and solidarity as a single weave. He and his colleagues, therefore, as evidenced in our national freedom struggle, developed social capital in their own way for resisting British imperialism. India and its democracy have faced conflicts in its ideological and political spheres; however, the nation has still continued to be woven as one fabric. It is imperative to note that linguistic organization of states in India is its strength, and each linguistic state can develop in its own right. The central powers, which are the main governing bodies, should coordinate this development which can contribute to the national growth and development as well (Sharma, 2013, p. 10).

China and the East Asian nations have strong education systems and as social capitals, these nations direct their energies more on social development than on safeguarding their special privileged status. This is the secret of the continuous development of these nations despite the adverse circumstances some of these nations have faced sometimes in the past (Mahbubani, 2006). Therefore, the idea of education should aim at the culminating outcome (Mahbubani, 2006, p. 215) for social capital development, and the idea of learning should aim at achieving a comprehensive outcome (Sen, 2009, p. 25) which is dependent on the processes, namely, the curriculum and the teacher. As mentioned earlier, this can be ensured by the total participation of all the stakeholders of the education system that would bring together the formal, nonformal, and informal collectively to develop strong social cohesion. This social strength will hold the nation and its society together in times of adversity and simultaneously, influence both development opportunity and outcomes. Culminating outcomes happen to be the result of the total involvement of the system for a purpose to develop such a social capital. This kind of social capital drives transformation and development while reducing the risk and 38 
transaction cost incurred for the process. To create this kind of social capital, following perspectives need to be highlighted:

1. Clarity of vision for growth

2. Professionalism in the performance being supported by work ethic

3. Convergence of performance of individuals towards a purpose and desired path

4. Sharing of information and resources

5. Networking of functionaries for realising the national goal

6. Readiness for managing the change

In spirit, this should be the mission of a system called 'National University' which should be holistic in its approach without compartmentalisation. The main culminating outcomes of such a system will be a cultural narrative for our country and functional nationalism, and the comprehensive outcome will be the networking of various institutions for knowledge and resource sharing on the foundation of this cultural narrative.

Sixth century BC was an important period in world history. In India, Takshashila was a great learning centre that was started under the patronage of great rulers who believed that education is a social force. In China, Confucianism initiated the worldview that considers education as a social force. In Europe similarly, the influence of the Greeks and Romans as great thinkers and rulers influenced the value and function of education in a society. Unfortunately, wars between the empires and religions (crusades) spoiled the social order. India suffered several invasions. An institution of eminence, Nalanda was quite significantly affected by the invasions. The colonial rule had a significant impact on the social, cultural, political, economic, and psychological aspects of our citizens. China, and East Asian nations did not become the colonies of the west. Therefore, they have retained their cultural and educational identity. In the west, the fall of the Roman Empire disturbed the fabric of the nation. It had to rediscover itself economically and educationally. Due to the scientists like Galileo, Isaac Newton and others, scientific inventions followed and the 
order of life started changing. Modified steam engine by James Watt revolutionised the order of life; industrialisation changed the social stratosphere. This had a greater impact on the education system which aimed to redesign the purpose of education driven by economic development. Education system thus became a system to develop social capital for economic development and for maintaining social order. East Asian nations showed a reasonable success in this race.

Any higher education institution needs to instill a sense of freedom in research and teaching. This academic freedom to examine and deliberate is essential for the development of teachers, students, and all stakeholders in education with a given context. A constrained, repressive environment is detrimental for a healthy development of an individual. Another crucial aspect that requires mention is that for a comprehensive perspective towards teaching and research should be interdependent. Similarly, for a student, learning and research should go hand in hand, one should complement the other.

Freedom to think begets development. Let us take note of a few examples:

1. Anang Tadar, a boy from grade $11^{\text {th }}$ from Arunachal created special goggles for the visually disabled individuals to help them without facing any obstacles. UNICEF has congratulated him for the innovativeness and his commitment to service. He has claimed that he was inspired to invent the device after he saw a small blind girl a few years ago (Business Standard, 2017).

2. 15-year-old Akash Manoj invented a device that detects 'silent' heart attacks. He spent one and a half years perfecting his machine with the help and guidance from AIIMS, Delhi. His personal encounter of his grandfather's death made him think about a device that could potentially save a large number of people (Dutt, 2017).

3. Harshwardhan Zala, a 14 year old from Gujarat made a laser drone that can detect and defuse landmines. He signed a Memorandum of Understanding with the Gujarat government for the same for the amount of 5 crores. He has 
claimed that he was inspired to do something positive for the soldiers; the landmines kill almost as many soldiers as the enemy does. Furthermore, they kill innocent people years after the war is over (Mishra, 2017).

Have we created a good university or higher education platform in India to foster the innovative temperament of the children like the above? Children like these are the hope of our country. If we see the motivation that has stimulated their mind to innovate, it becomes clear to anybody about their social commitment. This also provides support to the argument that learning and research is an integrated development. Have we created hope for them to escape the shackles of being caught in the web of degenerating social order? This sets out a larger purpose for our proposed National University.

We define National University as an educational organisation that 'looks within' and conducts research endeavours through networking with various institutions/universities within the country and overseas for the development of one's nation. This notion of a national university can empower by its performance as a creative system and as a social enterprise.

\section{State-of-the-Art}

Elite, for the purposes of the paper, refers to a group of individuals who exercise control directly or indirectly in an organisation which could be due to social positions occupied by them or due to their merit. A society is a conglomeration of different communities sharing some common element as a binding force - maybe the internalised national narrative or the sense of belonging to the nation and caring for its welfare, for example, communities of teachers, business class, peasants, salaried class, bureaucrats, and others form the constituents of the society (Dixit, 2016, p. 42). These constituent elements should work in unison for the welfare of the society. This was precisely the essence of Confucianism in education. Confucius was clear that the elite should be at the helm of affairs of governance and he promoted education for all. He was a firm believer of self-education following moral exemplars. He emphasised that skilled judgment is more important than the 
knowledge of rules. This was the foundation of education system laid down in China and consequently in Korea and Japan (Huanyin, 1999). Over the centuries, there may have been changes yet that cultural base of caring for the nation's good continues even today in these nations. However, education is the driver of development in these nations.

Combined with the functional nationalism and the positive attitude, Japan could stage a come-back after the World War II like a phoenix - due to its in-built rich educational foundation. Japan's strong moral education is synthesised by borrowing concepts from its own system, ideas from the west and the ideas from the Confucian system (Dixit, 2016, pp. 71-87). South Korea concentrated more on moral education and patriotism in school education till early 70s because of which during the IMF crisis from 1997 to 2001, citizens of South Korea gave away their material possessions to the nation and worked towards the rebuilding of the national economy. The nation staged a comeback to the surprise of the entire world and today it is a force to reckon in the manufacturing sector (Kim et al., 2000; Kim \& Seo, 2012; Williamson, 2012).

In Finland, play is a part of pedagogy to realise the goals of learning, and therefore pedagogy extends beyond curriculum. Education system in Finland not only develops social capital but also social cohesion and trust in the education system that facilitates a spirit of nationalism within students. The Ministry of education in Finland with two representatives from the ruling party and the other from the main opposition party during 1970 to 1987 set an example for the world politics. This model revealed that the education administration in a nation requires close political cooperation irrespective of political differences. Citizens are committed to the vision that education and economic development are important for their growth and survival. The teacher is the most respected citizen in Finland and only a real scholar can become a teacher there (Dixit, 2016, pp. 104-107).

The examples cited above are of smaller countries and could be evaluated before being treated as being not conducive for Indian conditions. But scholars (Kaul, 2013) argue that each state in the Indian federal system develops on its own without exploiting the 
national integrity. If the Indian federal system is seen from this perspective, the models of Finland or Japan or South Korea could be considered for each state as a unit. Following the educational policies laid down by the centre in collaboration with state governments, we could bring the required change in the Indian higher education context.

The current state-of-the-art in India's education system has a few issues. The most important one being that India does not yet have a national education narrative. There is a distinct disparity between agreed reforms and policies of the government and the total functioning of the education system. In the absence of a national narrative, institutions have to cope with articulating their contribution in creating institutions of national prominence. In the absence of the well-defined mission for education conforming to the national narrative, therefore, it is difficult to organise the processes towards comprehensive outcomes as a national good. Moreover, in the absence of organised processes conforming to the mission, educational thinkers and people within a university are unable to reflect on the evolution towards intellectual independence and the advancement of human knowledge as a national good. This has adverse effects on evolving progressive methods to sustain the character of higher education that represents national identity. Consequently, the lack of clarity and efficiency in our education system has led to several detrimental effects on the perception of university, the primary one being, the perception of what a university is and what it could contribute to for building national communities.

\section{Need of the hour and constitution of the national university}

In India, there are quite a few development study centres with an objective of conducting interdisciplinary development intensive research. These centres offer advanced degrees in interdisciplinary fields. Some centres like the Society for Development Studies (SDS), New Delhi conducts short term training programmes for skill / professional development in addition to the inter-disciplinary research endeavours. 
The Centre for Sustainable Technologies (CST) of the Indian Institute of Science, Bangalore, established with a focus on the Application of Science and Technology for Rural Areas in 1974, has made successful interventions like Energy Efficient Wood Burning Devices, Biomethanation, Biomass Gasification, Alternative Building Technologies, Green Buildings and BiPV, Water Purification and Defluoridation, Sanitation, Sustainable Biomass for Energy, Forestry, Bioenergy \& Climate Change, and Environmental Quality Assurance-Impact Studies. Interdisciplinary research takes place in this centre. But the reach may not be enough. Considering the size of the country there is a need for more number of similar centres to transfer technology to the public, in rural and urban areas. And there is a scope for designing vocational courses in these applications in vernacular for rural youth to create employment opportunities and entrepreneurship.

$67 \%$ of India's population is rural (The World Bank, 2014) and there is a need for rural management in a professional way. In the year 1979, an institute dedicated to train graduates in rural management was founded in Anand, Gujarat, India. The motivation for founding this institute was the work of Dr Verghese Kurien to create cooperatives in the field of dairy development. Institute of Rural Management Anand (IRMA) is an autonomous institution. This institute collaborates with co-operatives, NGOs (non-governmental organisation), governments, national and international agencies. This institute offers two-year postgraduate diploma in rural management and research in rural development. In the context of India, many such institutes are required to professionalise the rural management and development. This is an effort to see India from within and to sensitise the graduates to recognise the "India-Narrative." When our higher education institutions are boasting about the placements of their graduates abroad, being financially settled, IRMA is successfully training and conducting research for rural development in India. This gives us an idea about what may be the focus of our idea of National University. On the other hand, the AMUL experiment showcases the blending of rural raw productivity and advanced science and technology with a proper scientific management system to bring about a social change. This explained how a systematic supply chain management on a large scale can be devised as a model for 44 
the future of cooperatives in India. The AMUL model of milk products and distribution has been replicated in several areas in Indian and abroad.

India has 819 universities as on $29^{\text {th }}$ June 2017, NITs, IITs, IISc, IIMs, IISERs, AIIM Science, and autonomous institutes, agriculture universities, and the Indian School of Mines. In my observation, these universities can be classified into two categories Universities that customise and transfer the knowledge for the society including industries, service sectors and other user systems, and the others as centres of excellence which would create and enhance the knowledge base and focus on interaction and collaborations with other universities and centres of excellence overseas. In my opinion, it is desirable that the first category of universities collaborates with the second category for aligning the needs, understanding and requirement of research for an inclusive development of knowledge in a holistic manner.

India has come up with the National Skills Qualification Framework (NSQF). In this framework, there is a facility for both horizontal and vertical mobility with the facility for Recognition of Prior Learning (RPL), and National Certificate for Work Preparation (NCWP). Most importantly, with the RPL and NCWP, sociologically disadvantaged section of people can be included in the mainstream education process. This framework works on outcome-based learning that will provide for multiple pathways, horizontal as well as vertical, including vocational training, vocational education, and technical education while linking one level of education to the next higher level. This will enable a person to acquire desired competency levels, transit to the job market, and an appropriate time, return for acquiring additional skills to further upgrade their skills.

Nettur Technical Training Foundation (NTTF) has the resources for vocational education in technical education, and IRMA has the resources for professional rural management. Indira Gandhi National Open University has the model for managing education through regional centres and study centres.

The concept of the National University is to include the knowledge from various knowledge centres, synthesise, and innovate with the 
idea of locating and contextualising the same for the needs of India. The proposed university can use this knowhow as customised to the needs of curricular processes. Students of this university could be utilised as need identifiers similar to the models adopted by IRMA or Master of Social Welfare (MSW) programmes. Subsequently, the university-academia should explore the opportunities for knowledge transfer to engage with the local concerns. This could be considered as action research. It is both analysis and synthesis, maybe even innovation and evaluation sometimes. The proposed university therefore, will aim at interdisciplinary research, interdisciplinary qualifications at all levels following a framework like the NSQF so that the university can cater to all as an educational continuum from RPL level through level 10 seamlessly. Further, language should not become a barrier for learning. Developing English language skills is necessary at all levels of the qualification as appropriate to the level, but instruction may have to be in vernacular or native languages depending on the need of the students. An expertise in the English language will facilitate the candidate for horizontal and vertical mobility in the qualification framework seamlessly. This will also facilitate national networking for exchange of knowledge and expertise. Using technology and 'immersionism' as pedagogy, education may be taken to the learners.

\section{Conclusion}

This conceptualisation of a national University could create a national narrative and functional nationalism through social cohesion. In the process, the learner would develop ownership for his/her learning and become enabled. Skill / Vocational courses in vernacular or native languages could be seen as conducive for the development and inclusion of the rural youth in our education system. This approach could benefit the employment opportunities and entrepreneurship development for the nation. Action / experiential research as a pedagogic method and a knowledge building framework could encourage the participation of the youth and promote service towards society as a necessary element of national development. The networking of knowledge centres, and society to work collectively integrating teaching, learning, and 
research for national development could be seen as an important step for establishing linkages with society and creating the national weave which allows for plurality, knowledge, tolerance, service, and inclusivity.

\section{References}

Amartya, S. (2009). The idea of justice. Penguin Books: USA

Business Standard. (2017, March 27). Gadget guru AnangTadar creates history in world of technology. Retrieved from https://www.business-standard.com/article/news-ani/gadget-guruanang-tadar-creates-history-in-world-of-technology117032700468_1.html

Chandler, C., \& Zainulbhai, A. (Eds.). (2013). Reimagining India: unlocking the potential of Asia's next superpower. Simon and Schuster: New York.

Das, G. (2013). How to grow during the day. In C. Chandler \& A. Zainulbhai (Eds.). Reimagining India: unlocking the potential of Asia's next superpower. Simon and Schuster: New York.

Dixit, G. N. M. (2016). A call for educational renaissance in India. Swadeshi Parigyan Prasaran Prathistan (SMS Foundation): Pune.

Dutt, A. (2017, March 7). Meet Akash Manoj, a student who built device to predict 'silent' heart attacks. Hindustan Times. Retrieved from https:/ / www.hindustantimes.com/health-and-fitness/preventing-heart.

Gates, B. (2013). What I learned in the War (on Polio). In C. Chandler \& A. Zainulbhai (Eds.). Reimagining India: unlocking the potential of Asia's next superpower. Simon and Schuster: New York.

Huanyin, Y. CONFUCIUS (K'UNG TZU) (551-479 BC)(1999). Prospects: The Quarterly Review of Comparative Education (Paris, UNESCO: International Bureau of Education), Vol.XXIII, no.1/2, 1993, p 211-19. UNESCO: International Bureau of Education.http:// www.ibe.unesco.org/publications/ThinkersPdf/ confucie.PDF

Kim, C., \& Seo, E. K. (2012, October 31). ‘Gangnam Style' Tells Economic Truth of Our Day. Bloomberg News.

Kim, H., Cheong, H., Hoge, J. D., Sickle, R. L. V., \& Young, S. (2000, November 2010). Elementary moral education and social studies in South Korea. Retrieved from http:/www.socialstudies.org/ system/ files/publications/yl/1304/130402.html

Mahbubani, K. (2006). From Confucius to Kennedy: Principles of East Asian Governance. In I. Gill, Y. Huang, H. Kharas (Eds.), East Asian 
visions - perspectives on economic development, 135-165. The International Bank for Reconstruction and Development /

Mishra, R. (2017, January 13). HarshwardhanZala, 14-year-old trends for Rs 5 crore deal at Vibrant Gujarat Global Summit 2017! India. Retrieved from http://www.india.com/buzz/harshwardhan-zala-14year-old-trends-for-rs-5-crore-deal-at-vibrant-gujarat-global-summit2017-1758024/

The World Bank. (2014). Retrieved from https:// data.worldbank.org/indicator/SP.RUR.TOTL.ZS

Williamson, L. (2012, July 9). What Eurozone countries can learn from South Korea? BBC News Seoul. Retrieved from https:// www.bbc.com/news/business-18719079 